\title{
Performance Evaluation of Common Bean (Phaseolus vulgaris (L.)) Varieties at Benatsemay Woreda of South Omo Zone, SNNPR, Ethiopia
}

\author{
Misgana $\mathbf{M}^{1 *}$ and Tadesse $\mathbf{M}^{2}$ \\ ${ }^{1}$ Department of Plant Pathology, Ethiopia \\ ${ }^{2}$ Department of Plant Breeding, Ethiopia
}

Submission: October 24, 2017; Published: November 15, 2017

*Corresponding author: Misgana M, Department of Plant Pathology, Ethiopia, Email: misganamitiku441@gmail.com

\begin{abstract}
Common bean (Phaseolus vulgaris L.) is the second most important source of human dietary proteins and the third most important source of calories and also it has a high nutritional value with important protein contents $(\sim 22 \%)$, minerals (calcium, copper, iron, magnesium, manganese, zinc), and vitamins necessary to warrant the food security of people in the developing countries. A field experiment was conducted on farmer's field of Kako kebele of Benatsemay woreda of South Omo Zone of Southern Ethiopia using six improved common bean (Phaseolus vulgaris (L.)) varieties under rain fed condition in 2015. The objective of the study was to select the best performing common bean varieties that will increase productivity and production of common in the target areas. The treatments involved were six improved varieties of common bean Tatu, Remeda, Sari-1, Wajo, Ibado and Deme.

The experiment was carried out using a randomized complete block design (RCBD) with three replications at Kako in 2015. The result of analysis of variance showed that both of the phenological and yield and yield component parameters studied were significantly affected by varieties. In this study, there were significant variations observed among the common bean varieties for days to flowering, plant height, 1000 seed weight and grain yield. The effect of varieties on grain yield was significant and the best performing varieties of common bean namely Tatu $(1.033 \mathrm{~kg} / \mathrm{plot})$, Remeda (0.959kg/plot), Sari- $1(0.849 \mathrm{~kg} / \mathrm{plot})$ or Wajo $(0.908 \mathrm{~kg} / \mathrm{plot})$ would be recommended for the specific community and its vicinity even though further study should be carried out including a number of recently released varieties for improved common bean production in the target area and also to put the recommendation on strong basis.
\end{abstract}

Keywords: Common bean; Phenological parameters; Yield components; Varieties; Yield

\section{Introduction}

Common bean (Phaseolus vulgaris L.) is the second most important source of human dietary proteins and the third most important source of calories [1-3]. According to Miklas et al. [4], this crop has a high nutritional value with important protein contents $(\sim 22 \%)$, minerals (calcium, copper, iron, magnesium, manganese, zinc), and vitamins necessary to warrant the food security of people in the developing countries. P. Vulgaris is the most widely distributed Phaseolus species as it is grown across all the continents with a broad range of adaptation to various environmental conditions. Total national production was estimated at 5137.21 ton in 2014 [5].

It is the most important food legume in Latin America and East and Southern Africa. Common bean is a traditional crop of the neotropics, where it was domesticated several thousand years ago [6]. Though the total world production of the common bean could not be calculated with certainty due to confusion with other legumes in some of the data, but estimated between 11 and
12 million tons [7]. The total common bean production in subSaharan Africa is around 3.5 metric tons with $62 \%$ of production in East African countries of Burundi, DR Congo, Ethiopia, Kenya, Rwanda, Tanzania and Uganda, making this the most important region for the crop within the African continent [8]. The East African highlands are a region of important common bean production and high varietal diversity for the crop [9].

In Ethiopia, generally legumes are the major sources of protein where common bean accounts for the largest proportion next to faba bean and field pea $[10,11]$. It is one of the major grain legumes widely cultivated and grown as source of protein and cash by smallholder farmers by the smallholder farmers in the Southern Ethiopia [12]. Even if its production is concentrated at low land areas; but the extent of production of common bean in the target area especially in South Omo Zone is with the use of farmers' variety rather than the improved varieties so far. The lack of the improved varieties of common bean is the major 
problem that plays a great role for the lower yield of the common bean in the study area.

The lack of improved varieties is one of the top problems for low yield of common bean [13]. Therefore, there is need to introduce the improved common bean varieties to the target area is paramount important to come up with improved productivity and production of common bean in the study area. So, this research was initiated with the objective of selecting the best performing common bean varieties in the study area.

\section{Materials and Methods}

\section{Description of the study area}

The experiment was conducted at Kako farmer's field located at $036^{\circ} 40.259^{\prime} \mathrm{E}$ longitude and $05^{\circ} 38.332^{\prime} \mathrm{N}$ latitude and at an altitude of 1305 meters above sea level (masl). Geographically, Kako is situated in South Ethiopia at about $711 \mathrm{kms}$ from the Addis Ababa. The long term weather data of the area revealed that the mean annual rainfall of the area is $68.14 \mathrm{~mm}$ with a range of 32.59 to $115.96 \mathrm{~mm}$. The experiment was conducted during the main cropping season (April to July, 2015) under rain fed conditions.

\section{Treatments and experimental design}

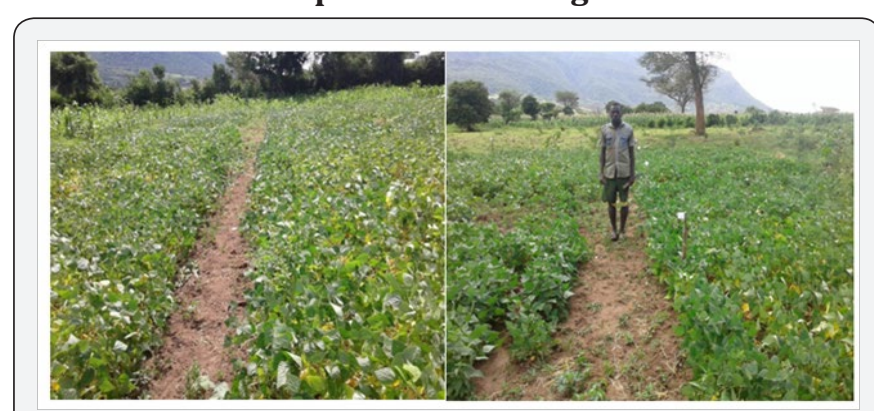

Figure 1: Field performance of Common Bean Varieties.

The treatments involved were six improved varieties of common bean namely; Tatu, Remeda, Sari-1, Wajo, Ibado and Results and Discussion
Demi. The experiment consisted of 6 treatments with a total of 18 plots. The field experiment was laid out in a randomized complete block design (RCBD) with three replications. Common bean was shown on April 28, 2015 in five rows per plot with spacing of 3 meters length with row-to-row distance of $40 \mathrm{~cm}$ and plant-to-plant distance of $10 \mathrm{~cm} .100 \mathrm{~kg} / \mathrm{ha}$ of DAP were applied during planting (Figure 1).

\section{Data collection}

Phenological parameters: Phenological parameters such as days to flowering and days to maturity were recorded. Days to flowering was recorded by counting the number of days after emergence when $50 \%$ of the plants per plot had the first open flower. Days to maturity was recorded when $95 \%$ of pods matured per plot.

Grain yield and yield components: Three central rows were harvested for determination of grain yield. Grain yield was adjusted to $14 \%$ moisture content. Five plants were randomly selected from the four central rows to determine yield and yield components, which consisted of number of pods per plant and number of seeds per pod. Pod number per plant was determined by counting pods of the five randomly selected plants while number of seeds per pod was recorded by counting the total number of seeds in a pod from ten randomly sampled pods taken from the five randomly selected plants. 1000 Seed weight was determined by taking a random sample of 1000 seeds and adjusted them to $14 \%$ moisture content.

\section{Statistical analysis}

All collected data were being subjected to analysis using the SAS (statistical software).The analysis of variance was also performed using the GLM procedure of SAS Statistical Software. Effects were considered significant in all statistical calculations if the P-values were $<0.05$. Means were separated using Tukey's Least Significant Difference (LSD) test.

Table 1: Mean Square Values for Crop Phenology, Yield and Yield Components of Common Bean as Influenced by Variety at Kako, in 2015. * and ${ }^{* *}$ indicate significance at $\mathrm{P}<0.05$ and $\mathrm{P}<0.001$, respectively and ' $n s^{\prime}$ ' indicate non-significant.

\begin{tabular}{|c|c|c|c|c|c|c|c|c|}
\hline $\begin{array}{c}\text { Source of } \\
\text { Variation }\end{array}$ & df & $\begin{array}{c}\text { Days to } \\
\text { Flowering }\end{array}$ & $\begin{array}{c}\text { Days to } \\
\text { Maturity }\end{array}$ & $\begin{array}{c}\text { Pods } \\
\text { (Plant-1 ) }\end{array}$ & $\begin{array}{c}\text { Seeds } \\
\text { (Pod-1) }\end{array}$ & $\begin{array}{c}\text { Plant } \\
\text { Height(cm) }\end{array}$ & $\begin{array}{c}\text { 1000 Seed } \\
\text { Weight }\end{array}$ & \begin{tabular}{c} 
Grain Yield \\
\hline Replication (R)
\end{tabular} \\
\hline Treatment (Trt) & 5 & $1.388 \mathrm{~ns}$ & $4.166 \mathrm{~ns}$ & $1.6284 \mathrm{~ns}$ & $0.762 \mathrm{~ns}$ & $84.202 \mathrm{~s}$ & $194.802 \mathrm{~ns}$ & $9805.61 \mathrm{~ns}$ \\
\hline Error (E) & 1 & $17.555^{*}$ & $11.033 \mathrm{~ns}$ & $2.756 \mathrm{~ns}$ & $1.144 \mathrm{~ns}$ & $3208.68^{* * *}$ & $132850.735^{* * *}$ & $427861.45^{*}$ \\
\hline
\end{tabular}

The result of analysis of variance depicted that, plant height and 1000 seed weight were highly significantly different at $(\mathrm{P}<0.001)$ (Table 1). This indicates that there exists a linear response of the studied phenological parameters to varieties. The result of analysis of variance for mean squares revealed that, days to flowering and grain yield were significantly different at $(\mathrm{P}<0.05)$ (Table 1). The maximum and minimum number of pods plant-1 of (8.51) and (5.73) were recorded for the varieties Wajo and Sari-1ima, respectively (Table 2).
In this study, number of days to maturity, podsplant-1and seeds pod-1 was not significantly affected due to varieties (Table 1). The maximum and minimum number of seeds pod-1 of (4.73) and (3.00) were noted for the varieties Wajo and Tatu bean, respectively (Table 2). The above findings revealed that the maximum number of pods per plant and the highest number of seeds per pod resulted in the minimum grain yield of $(0.03 \mathrm{~kg} /$ plot) for the common bean variety Wajo which disagree with the finding of Tekle et al. 2014 which stated that, the maximum 
number of pods per plant and the highest number of seeds per pod resulted in the maximum grain yield of (2.1478tha-1) for the common bean variety Dinkinesh. In this experiment, grain yield of common bean was significantly different at $(\mathrm{P}<0.01)$ (Table1) and affected by the tested varieties. This finding agrees with the previous findings reported [12,13]. The highest grain yield of (1033.8) was recorded for the variety Tatu and the least grain yield of (31.4) was noted for the local check (Table 2).

Table 2: Crop Phenology, Yield and Yield Components of Common Bean as Affected by Variety at Kako, in 2015.

\begin{tabular}{|c|c|c|c|c|c|c|c|}
\hline Varieties & $\begin{array}{l}\text { Days to } \\
\text { Flowering }\end{array}$ & $\begin{array}{l}\text { Days to } \\
\text { Maturity }\end{array}$ & Pods (Plant-1) & $\begin{array}{l}\text { Seeds (Pod- } \\
\text { 1) }\end{array}$ & Plant Height $(\mathrm{cm})$ & 100 Seed Weight & $\begin{array}{r}\text { Grain Yield (Kg/ } \\
\text { Plot) }\end{array}$ \\
\hline Tatu & $41.000 \mathrm{C}$ & $71.000 \mathrm{~A}$ & $7.000 \mathrm{~A}$ & $3.00 \mathrm{~A}$ & 48.93C & $451.33 \mathrm{C}$ & $1.033 \mathrm{~A}$ \\
\hline Remeda & $43.000 \mathrm{BC}$ & $74.333 \mathrm{~A}$ & $6.200 \mathrm{~A}$ & $3.13 \mathrm{~A}$ & 81.87B & 466.17C & 0.959.A \\
\hline Sari-1 & $44.667 \mathrm{AB}$ & $72.667 \mathrm{~A}$ & $5.733 \mathrm{~A}$ & $3.40 \mathrm{~A}$ & $50.53 \mathrm{C}$ & $535.00 \mathrm{~B}$ & $0.849 \mathrm{~A}$ \\
\hline Wajo & $48.000 \mathrm{~A}$ & $76.667 \mathrm{~A}$ & $8.516 \mathrm{~A}$ & $4.7333 \mathrm{~A}$ & $131.83 \mathrm{~A}$ & $908.33 \mathrm{~A}$ & $0.031 \mathrm{~B}$ \\
\hline Ibado & $46.000 \mathrm{AB}$ & $72.667 \mathrm{~A}$ & $7.133 \mathrm{~A}$ & $3.5333 \mathrm{~A}$ & $57.07 \mathrm{C}$ & $272.50 \mathrm{D}$ & $0.918 \mathrm{~A}$ \\
\hline Deme & $44.000 \mathrm{BC}$ & $73.667 \mathrm{~A}$ & $7.200 \mathrm{~A}$ & $3.6667 \mathrm{~A}$ & 97.93B & $480.93 \mathrm{BC}$ & $0.555 . \mathrm{AB}$ \\
\hline LSD 0.05 & 3.336 & 3.3366 & 23.436 & 6.7379 & 23.316 & 2.4326 & 0.524 \\
\hline $\mathrm{CV} \%$ & 2.651 & 3.248 & 34.174 & 24.014 & 10.554 & 4.582 & 25.58 \\
\hline
\end{tabular}

\section{Summary and Conclusion}

Production of common bean by introducing the improved and high yielding varieties could make an important contribution to increase agricultural production and productivity in areas like Kako where there is low practice of using improved varieties of common bean. To this end, using the improved common bean varieties could be one of the options to improve productivity by small farmers. However, production of common bean using the improved varieties is not yet introduced and studied in the target area. Thus, this research work was initiated to examine the impact of improved varieties on the performance of common bean.

This Study carried out at Kako kebele of Benatsemay woreda of South Omo zone of SNNPR, Ethiopia under rain fed condition in 2015. The objective of the study was to select the best performing varieties that will improve common bean production in the studied area. The experiment was carried out using the randomized complete block design (RCBD) with three replications at Kako kebeles in 2014. Treatments involved in this experiment were six improved common bean varieties. The result of analysis of variance showed that both of the phenological and yield and yield component parameters were significantly affected by varieties.

In this study, there were significant variations observed among the common bean varieties for days to flowering, plant height, 1000 seed weight and grain yield. The effect of varieties on grain yield was significant and the best performing varieties of common bean namely Tatu (1033.8), Remeda (959.0), Sari1 (849.5) or Wajo (908.33) would be recommended for the specific community and its vicinity even though further study should be carried out including a number of recently released varieties for improved common bean production in the target area and also to put the recommendation on strong basis.

\section{References}

1. Bennink M (2005) Eat beans for good health. Annual Report of the Bean Improvement Cooperative 48: 1-5.

2. Widers IE (2006) The beans for health alliance: A public-private sector partnership to support research on the nutritional and health attributes of beans. Annual report. Bean Improvement Cooperative 49: 3-5.

3. Sarikamis G, Yasar F, Bakir M, Kazan K, Ergul A (2009) Genetic characterization of green bean (Phaseolus vulgaris) genotypes from eastern Turkey. Genet Mol Res 8(3): 880-887.

4. Miklas NP, Kelly JD, Beebe SE, Blair MW (2006) Common bean breeding for resistance against biotic and abiotic stresses: From classical to Marker assisted selection breeding. Euphytica 147(1-2): 105-131.

5. CSA Central Statistical Agency, (2014) Report on the preliminary results of area, production yield of temporary crops. CSA publication, Addis Ababa, Ethiopia, p. 16.

6. Freytag GF, Debouck DG (2002) Taxonomy, distribution and ecology of the genus Phaseolus (Leguminosae-Papilionoideae) in North America, Mexico and Central America. Sida, Botanical Miscellany 23. Botanical Research Institute of Texas, Fort Worth, TX, USA, p. 300.

7. FAOSTAT (2006) Statistical Databases.

8. Broughton WJ, Hernández G, Blair M, Beebe S, Gepts P, et al. (2003) Beans (Phaseolus spp.) Model food legumes. Plant Soil 252(1): 55-128.

9. Fivawo NC, Msolla SN (2011) The diversity of common bean landraces in Tanzania Tanzanian Journal of Natural and Applied Sciences 2(1): 1821-7249.

10. CSA Central Statistical Agency, (2010) Crop production forecast sample survey, 2010/11 (2003 E.C.). Report on area and crop production forecast for major grain crops (for private peasant holding, meher season). CSA, Addis Ababa, Ethiopia.

11. CSA Central Statistical Agency, (2011) Agricultural sample survey 2010/2011 (2003 E.C.). Report on area and production of major crops. CSA, Addis Ababa, Ethiopia.

12. Fekadu G (2013) Assessment of Farmers' Criteria for Common Bean Variety Selection: The case of Umbullo Watershed in Sidama Zone of the Southern Region of Ethiopia. Ethiopian journal for research and innovation foresight 5(2): 4-13. 
13. Fekadu G (2007) Participatory Varietal Selection of Haricot Bean (Phaseolus vulgaris L.) Varieties in UmbulloWacho and Beresa Watersheds in the Southern Region. In: Operational Research and
Capacity Building for Food Security and Sustainable Livelihoods. Proceedings of Irish Aid Supported Operational Research Review Workshop 11-13 January 2007. Hawassa University, Awassa, Ethiopia.

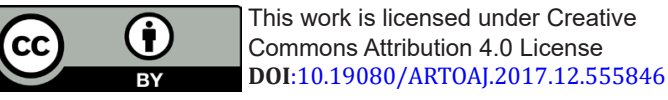

\begin{tabular}{l} 
Your next submission with Juniper Publishers \\
will reach you the below assets \\
- Quality Editorial service \\
- Swift Peer Review \\
- Reprints availability \\
- E-prints Service \\
- Manuscript Podcast for convenient understanding \\
- Global attainment for your research \\
- Manuscript accessibility in different formats \\
( Pdf, E-pub, Full Text, Audio) \\
- Unceasing customer service \\
Track the below URL for one-step submission \\
https://juniperpublishers.com/online-submission.php \\
\hline
\end{tabular}

